\title{
PROGRESS IN OPEN ROTOR RESEARCH: A U.S. PERSPECTIVE
}

\section{GT2015-42203}

Dale E. Van Zante

NASA Glenn Research Center

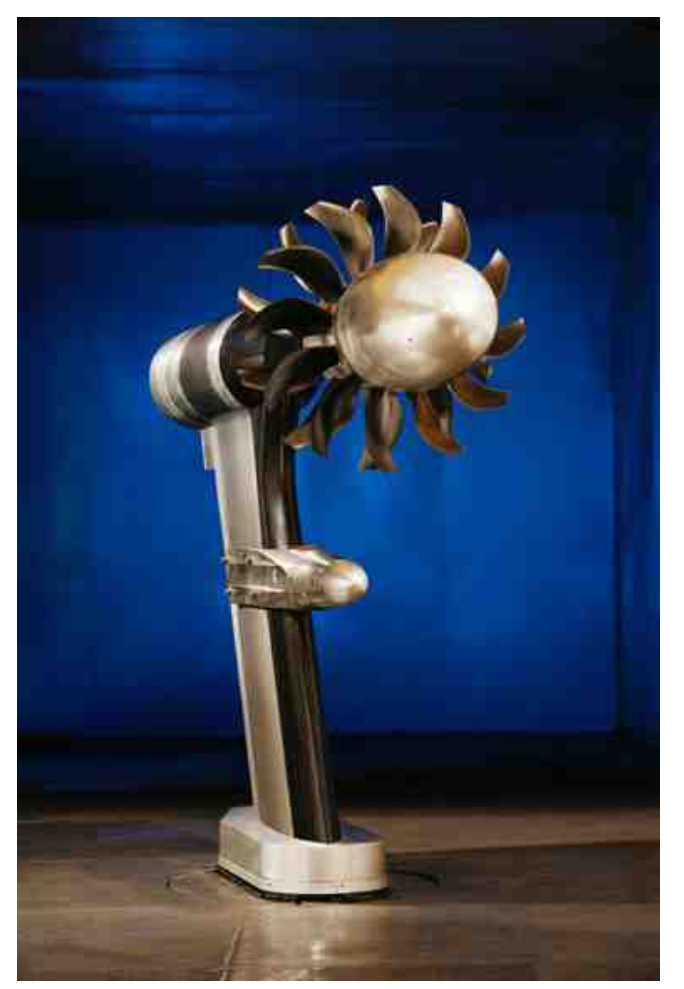




\section{Motivation}

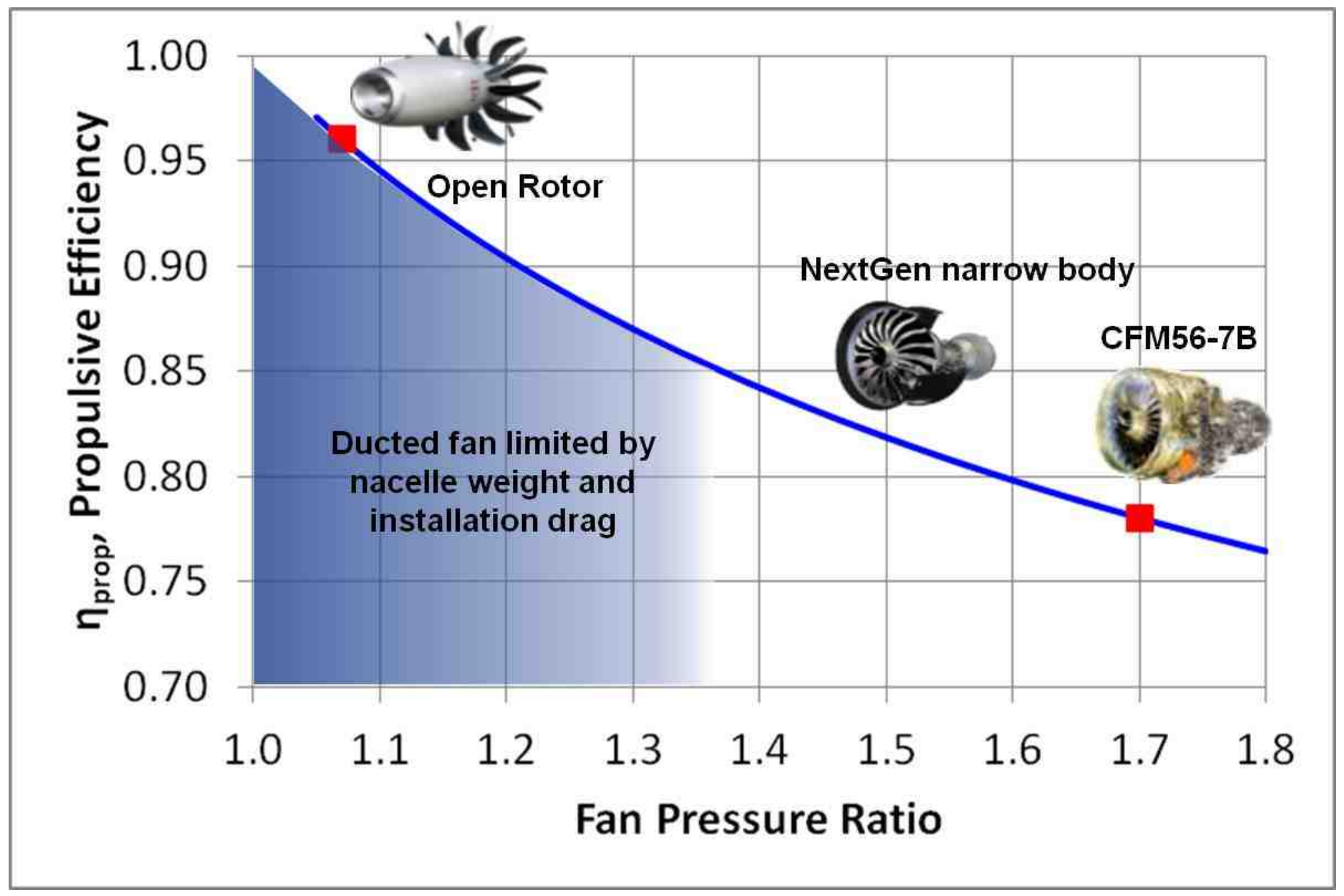

Low FPR systems for reduced fuel burn at acceptable noise levels. 


\section{Overviews}

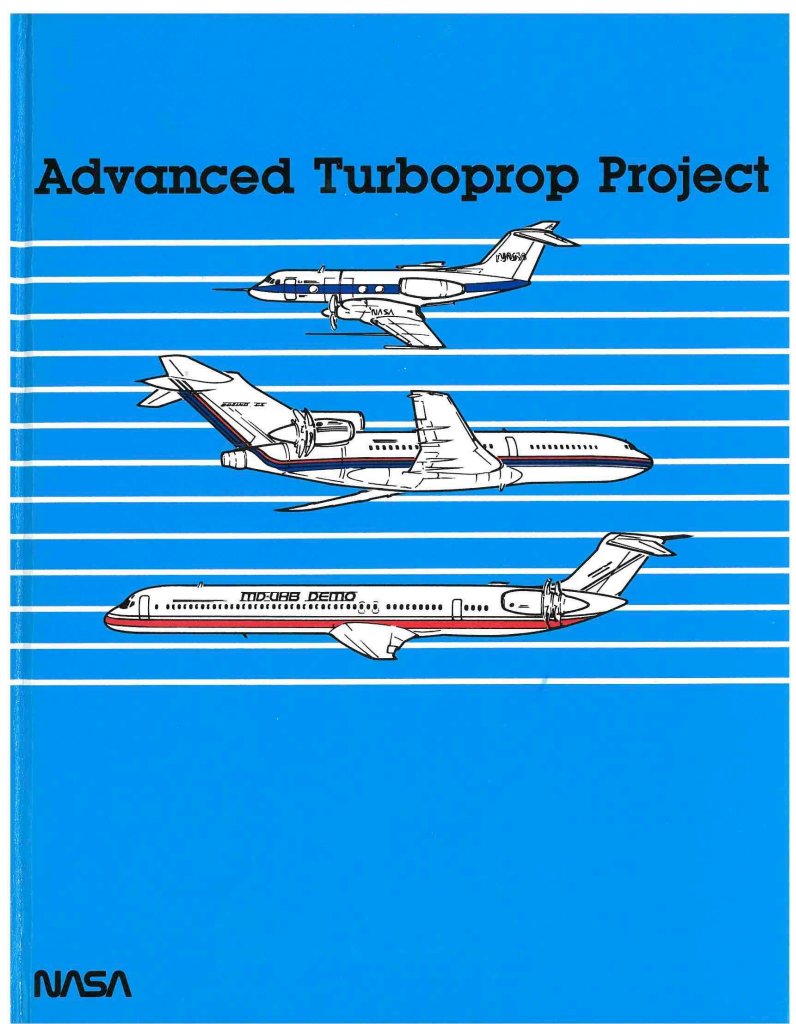

NASA SP-495, 1988

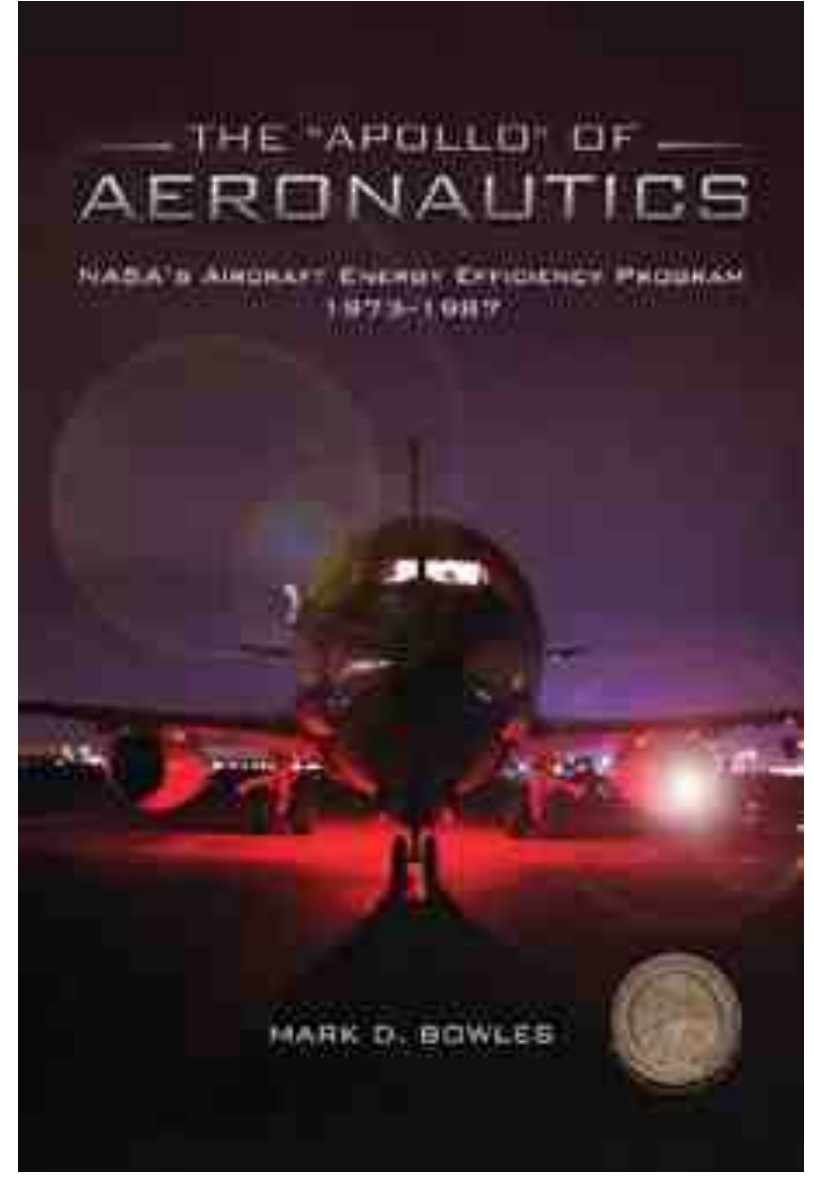

NASA SP-2009-574, 2010 


\section{Advanced Turboprop Program (ATP)}

C-1986-9461

Lewis Research Center

Mnsh

ADVANCED TURBOPROP PROGRAM
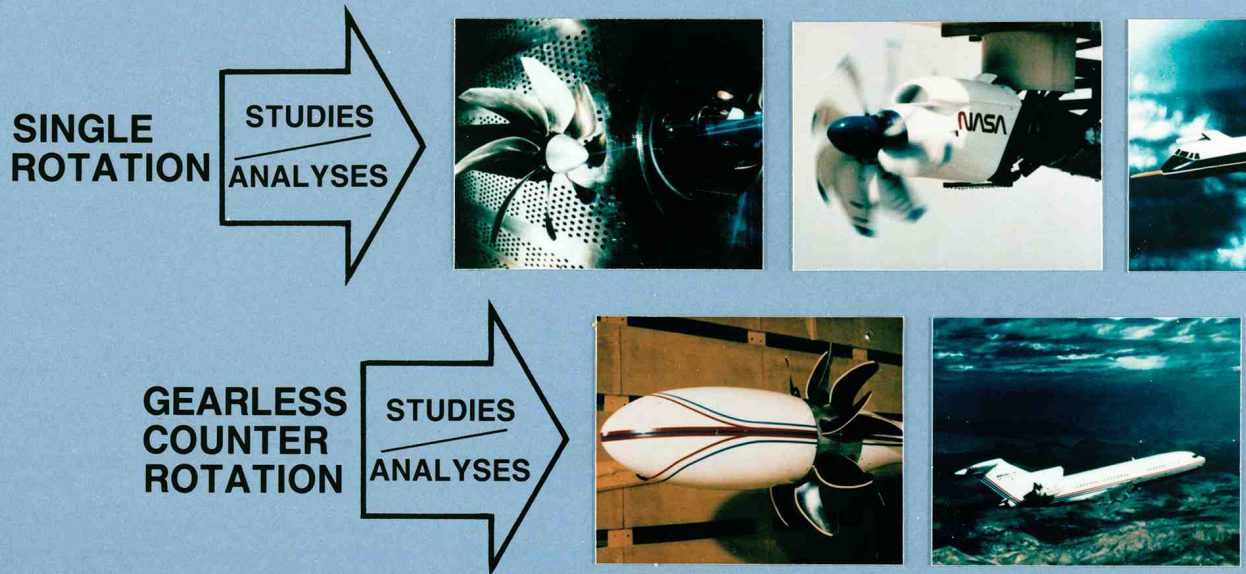

ROTATION
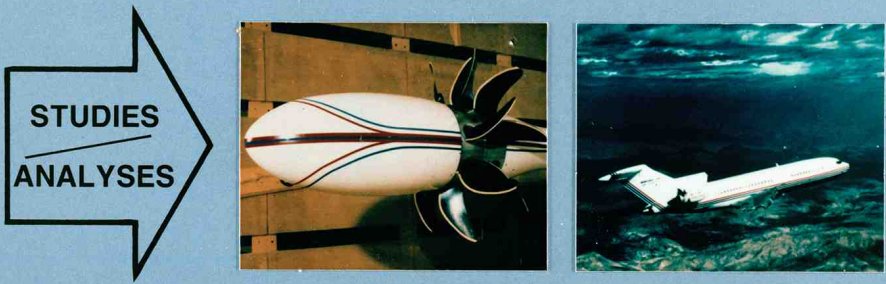

ADVANCED
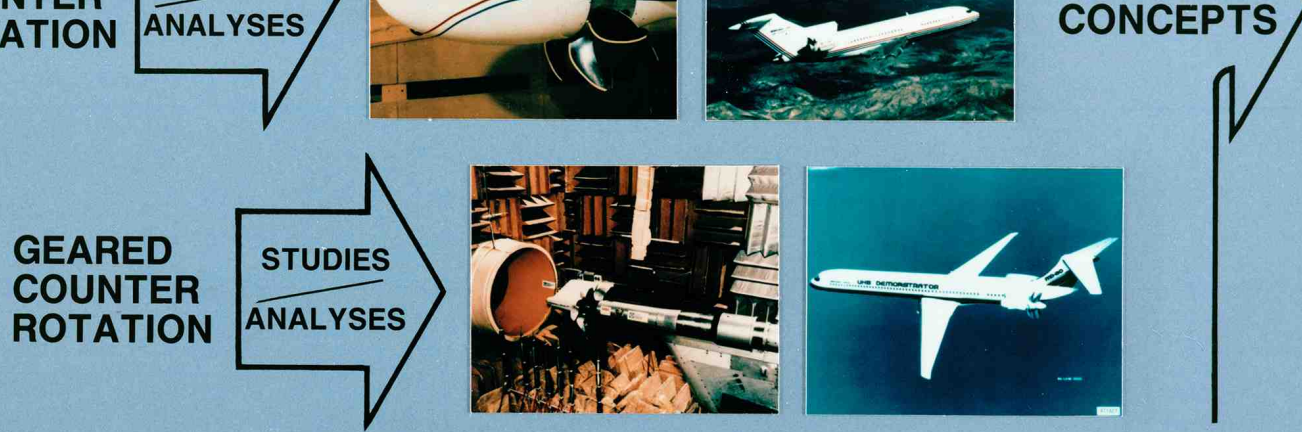

FY

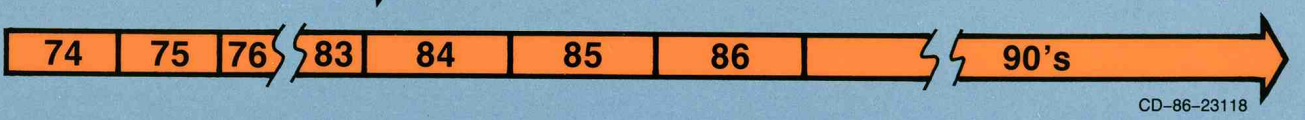




\section{Extensive Wind Tunnel Test program}

\section{(NASA C-1986-7568}

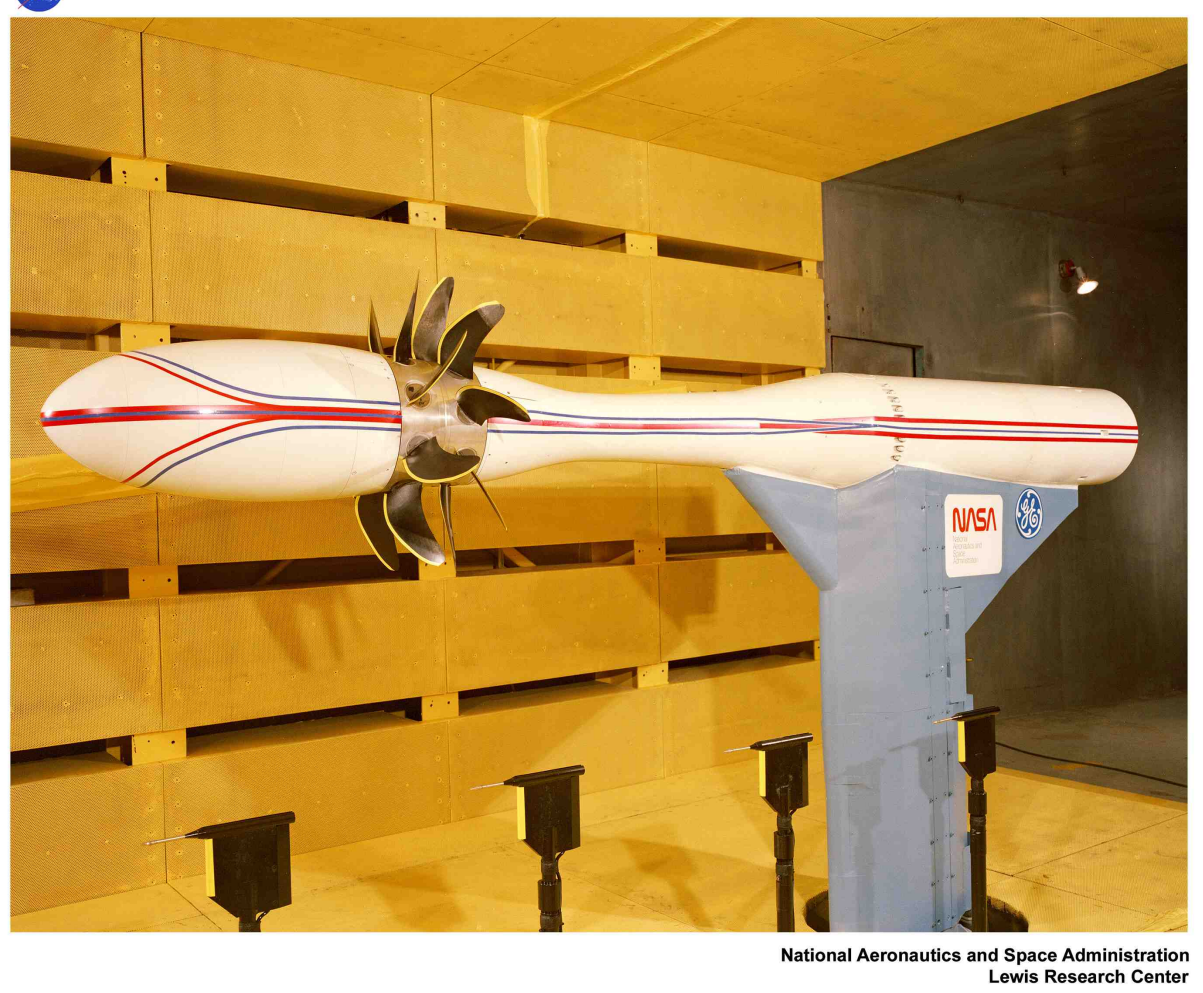

NASA Contra-Rotating Rig in 9x15 LSWT

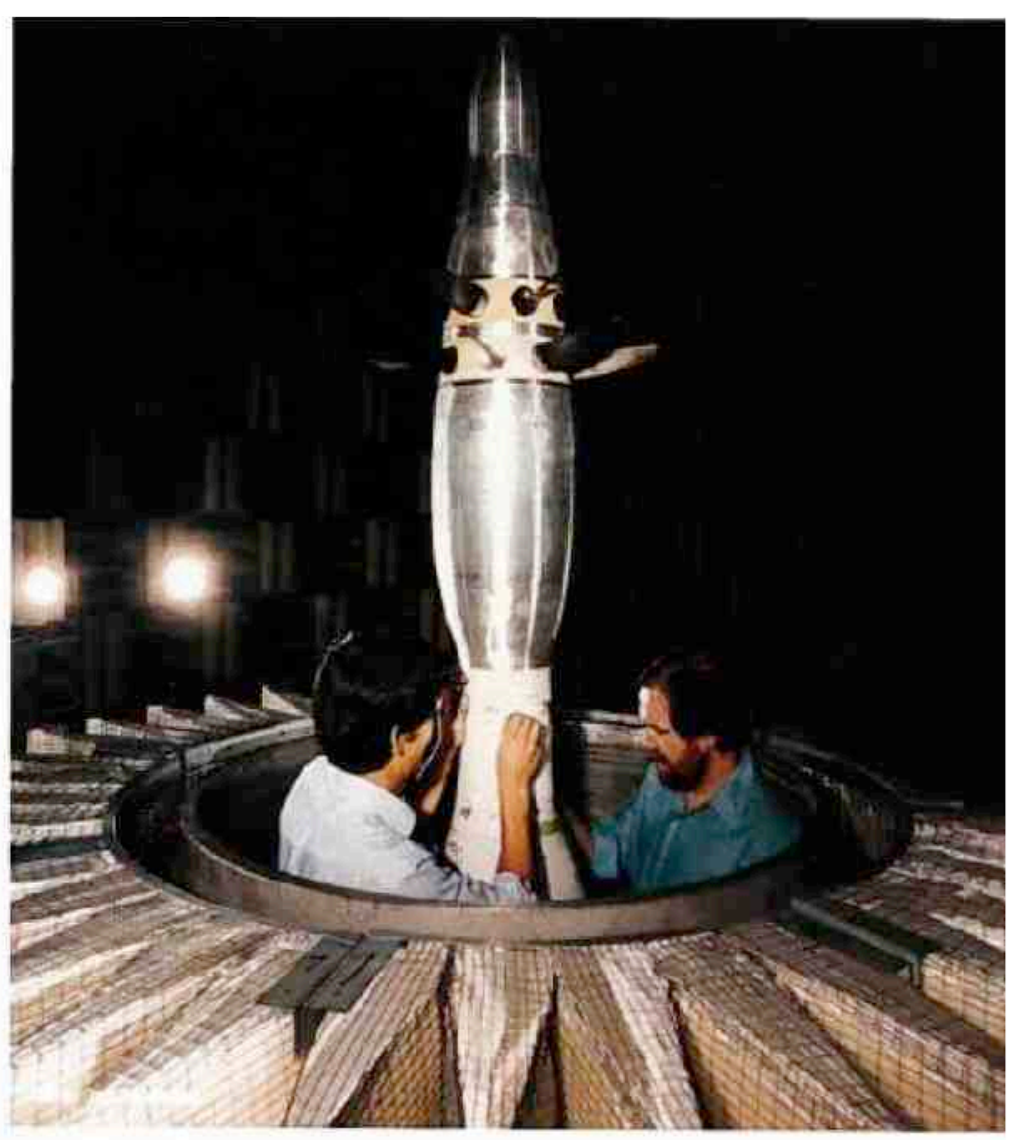

GE Contra-Rotating Rig in Cell 41 (from $X$-Noise 2011) 

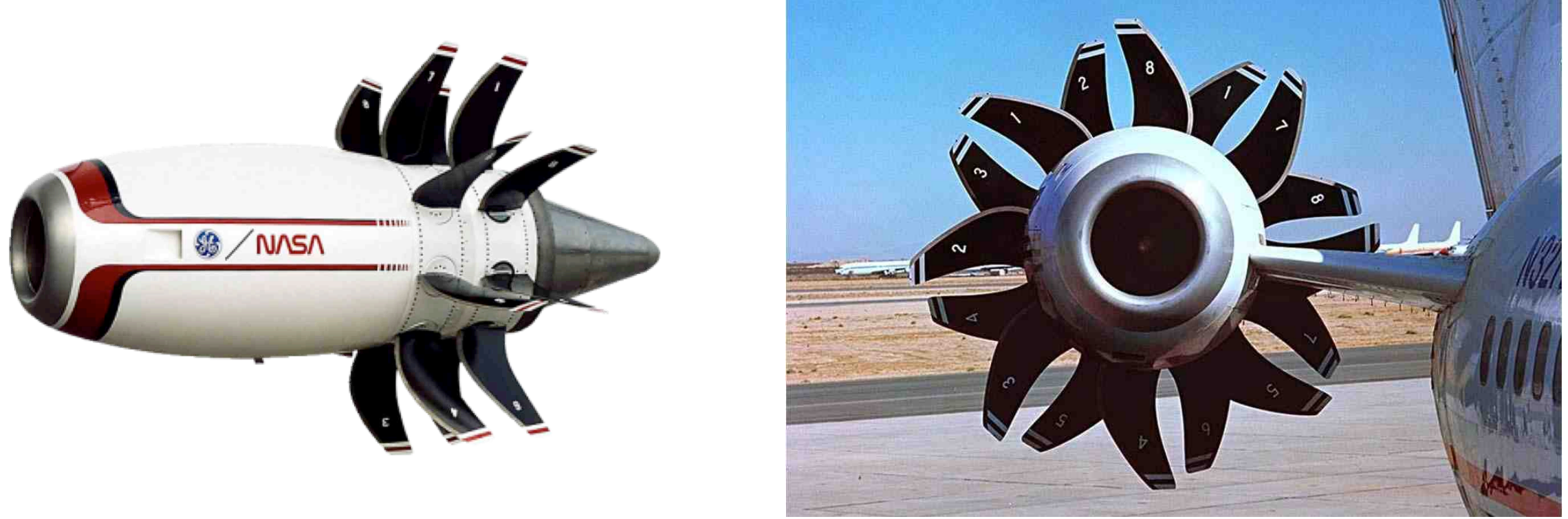

The UDFTM engine used an early blade design, F7/A7. It had a distinctive look and sound. 


\section{Advanced Concepts}

NASA C-1984-1348

\section{N/SA}

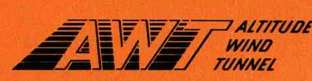

\section{FUTURE OF ADVANCED TURBOPROP}
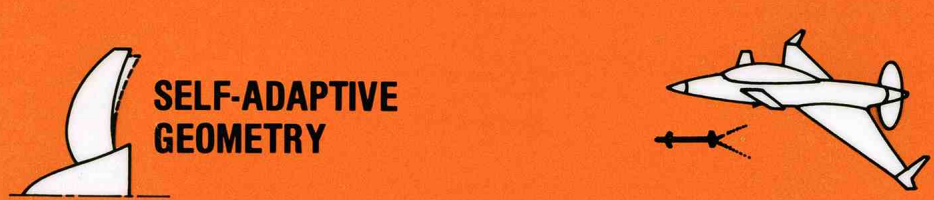

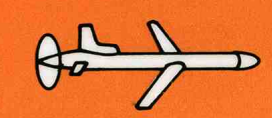

\section{SYSTEMS}

$A$ blowing INTEGRATION

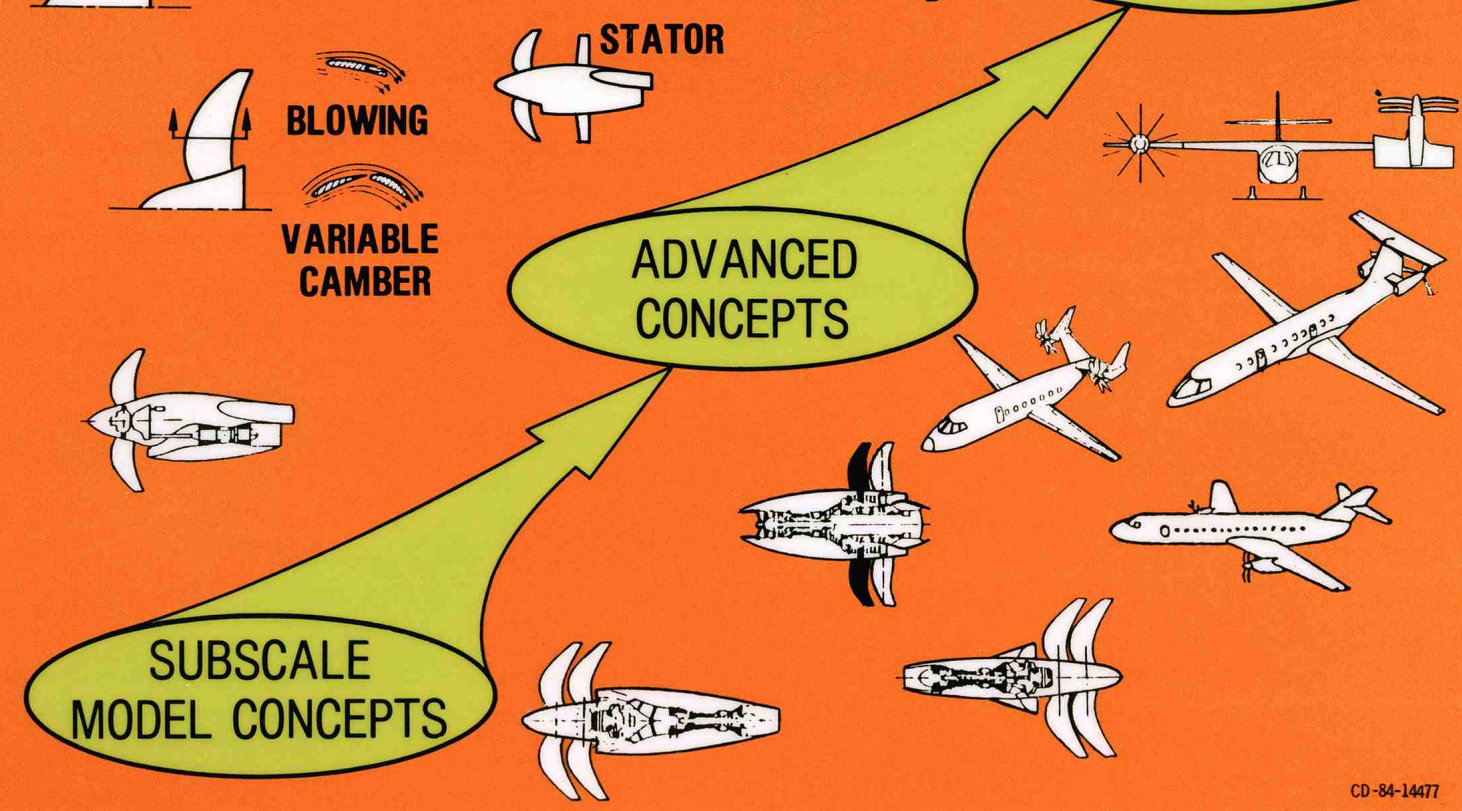




\section{Advanced Concepts: Forward Swept Rotor}

(Aㅗㅇㅕ C-1992-5894

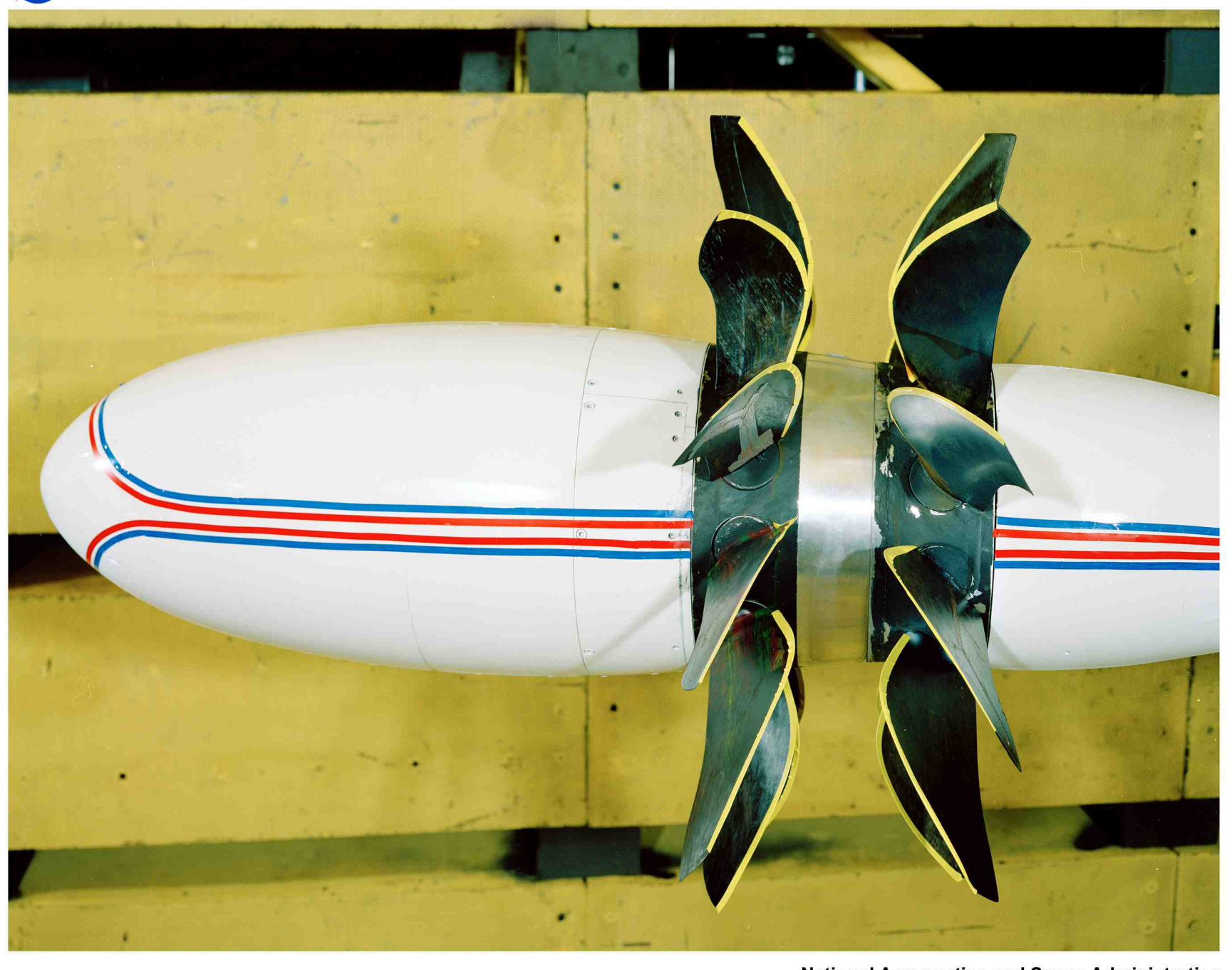




\section{GE36 Development}

GE36 Program Milestones

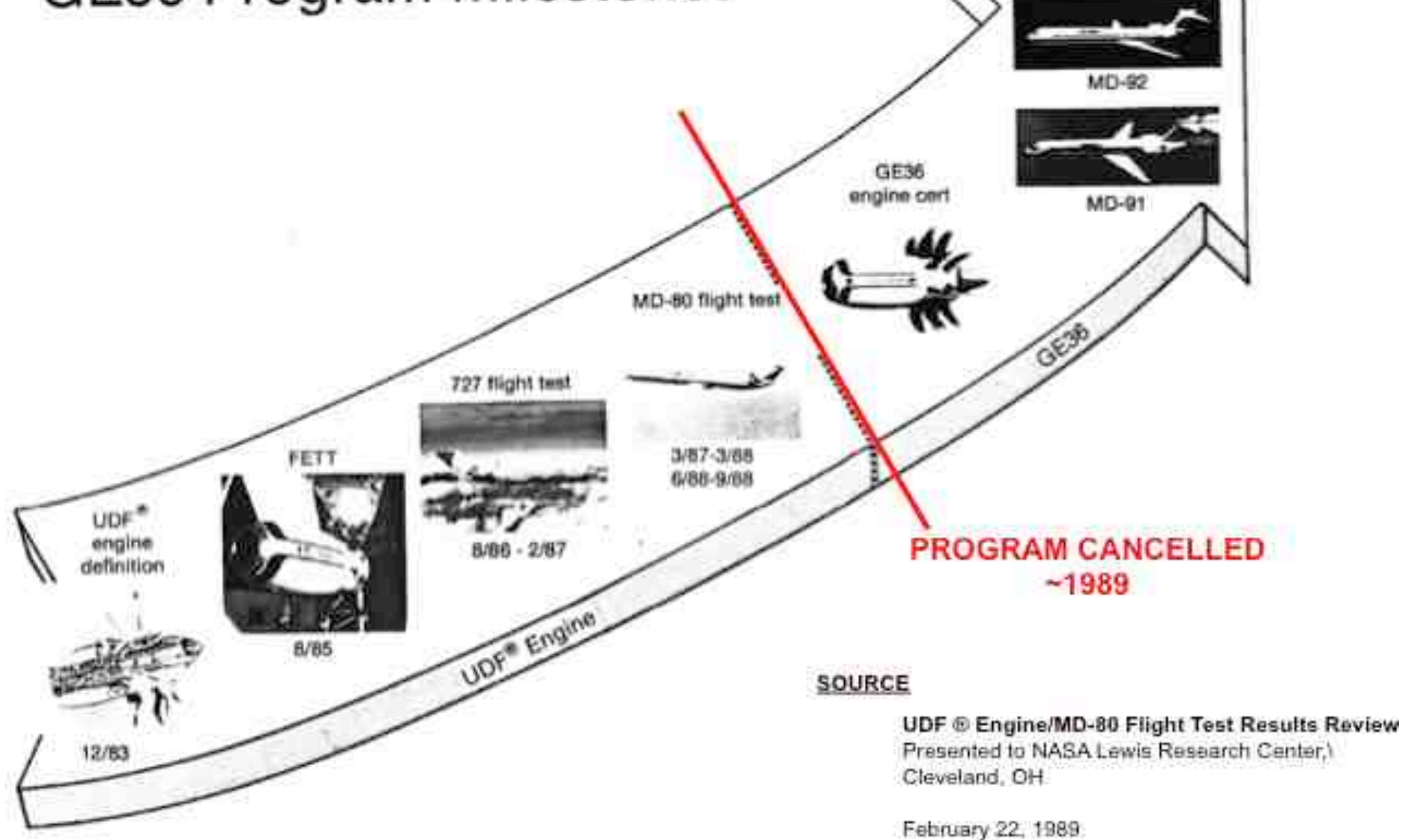

X-Noise, March 2011 


\section{Legacy of UDFTM work}

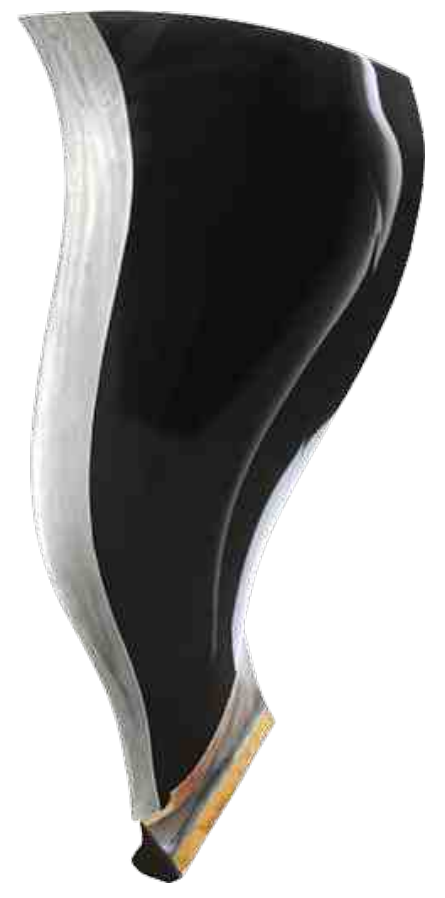

GE90 Composite Fan Blade (geaviation.com)

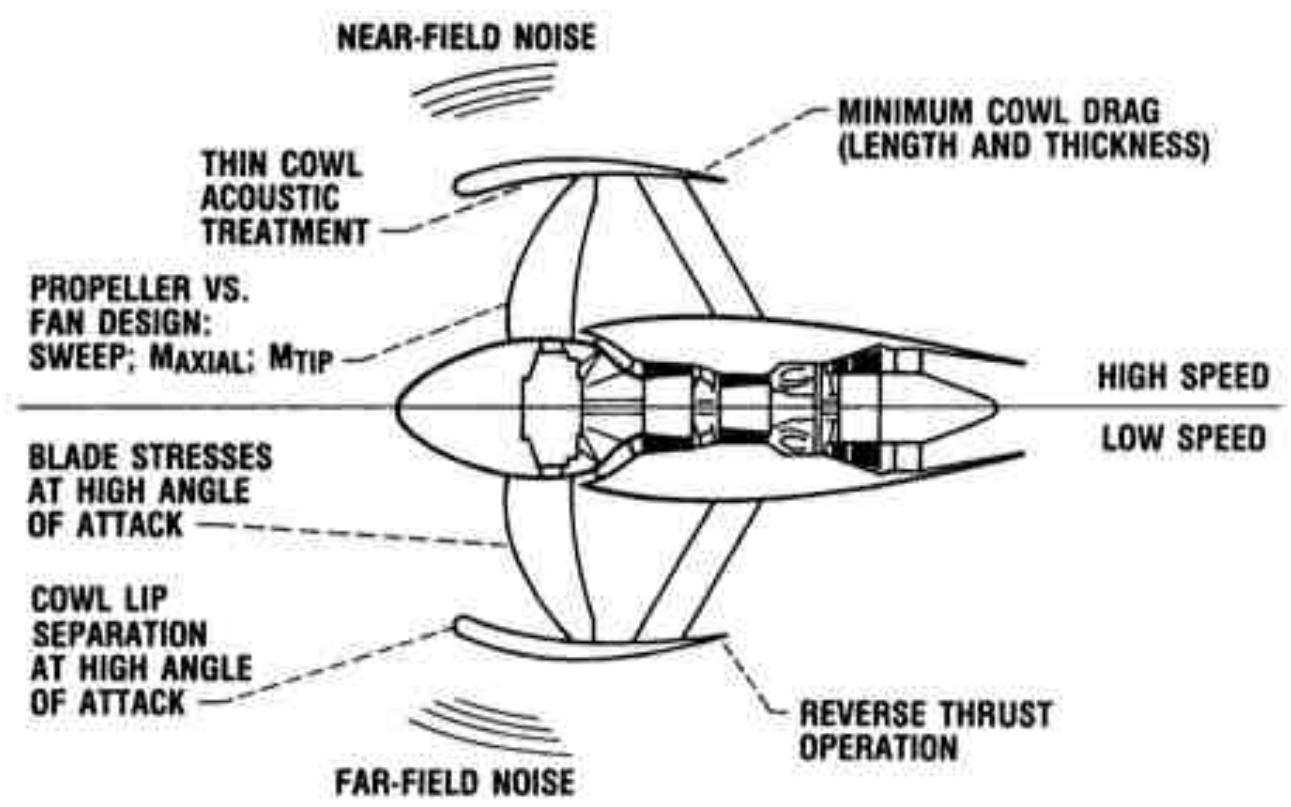

Low FPR Ducted concepts (NASA TM-101361)

Research focus returned to ducted systems. 


\section{Back to the Future}

\section{Keynote Session}

New Benchmarks for Gas Turbine and Jet Engine Advancements

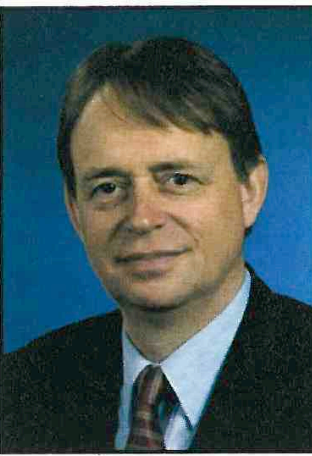

August Wilhelm Henningsen

Chairman of the Executive Board

Lufthansa Technik AG

With Lufthansa since 1979, Mr. Henningsen has overseen various areas of the company, including: the flight operation department; the aircraft-control group; aircraft

structure and systems engineering; aircraft cabins and

systems; and the overhaul line of the Boeing 737 fleet.

With the formation of Lufthansa Technik AG (LHT) in

1993, he took charge of the aircraft components services

division of the new company. A member of LHT's

Executive Board since 2000, when he was placed in

charge of the newly created MRO product and services

division, Mr. Henningsen became Chairman of the

Executive Board in 2001

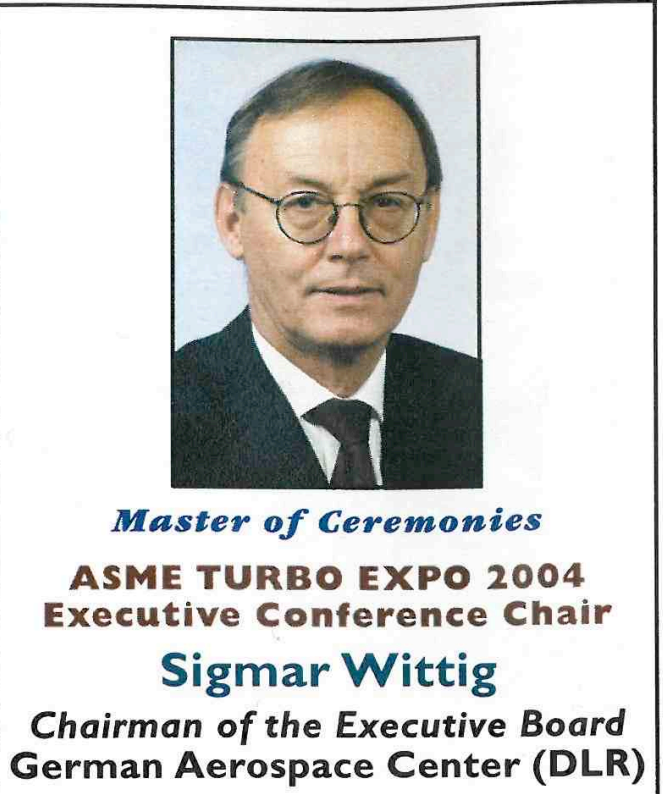

Lufthansa expressed the desire for lower fuel burn engine technologies.

Similar sentiments are in:

Epilogue: From Shock to Trance "How quickly we forget our history..." Bowles, SP-2009-574 


\section{Next Generation Open Rotors}

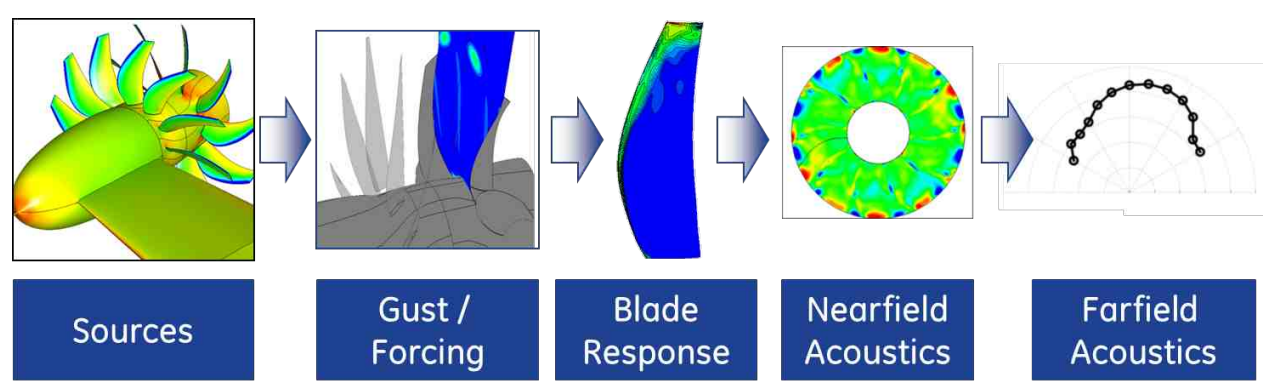

Contemporary design systems enable the simultaneous optimization for both aerodynamics and acoustics.

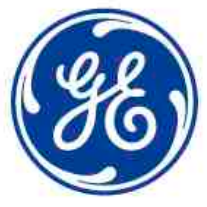

imagination at work

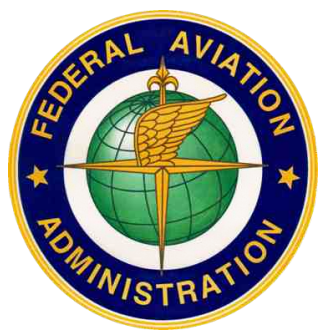

FAA Continuous Lower Emission, Energy and Noise (CLEEN) Program

NASA Environmentally Responsible Aviation (ERA)

NASA Fixed Wing (FW)

NASA Aeronautics Test Program (ATP)
(2.2.2010.3004

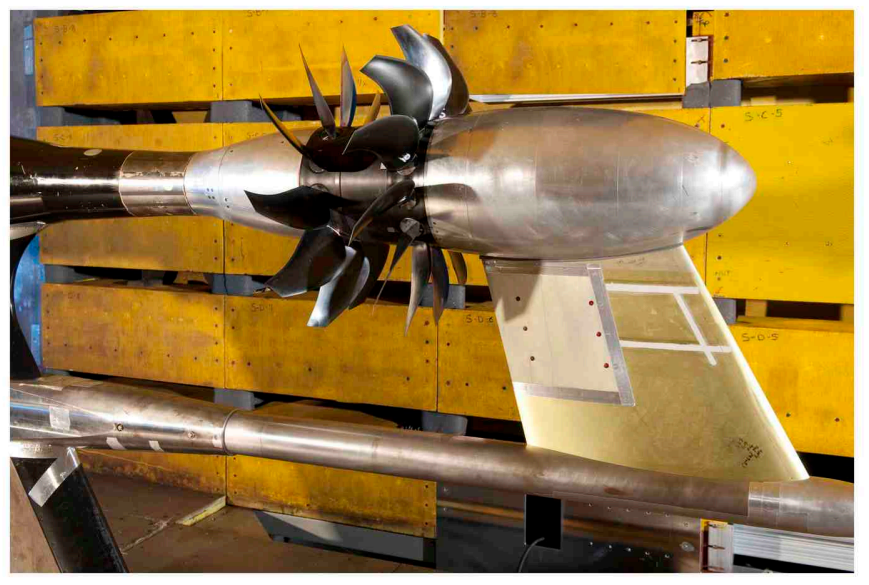

National Aeronautics and Space Administration
Gienn Research Center at Lewis Field

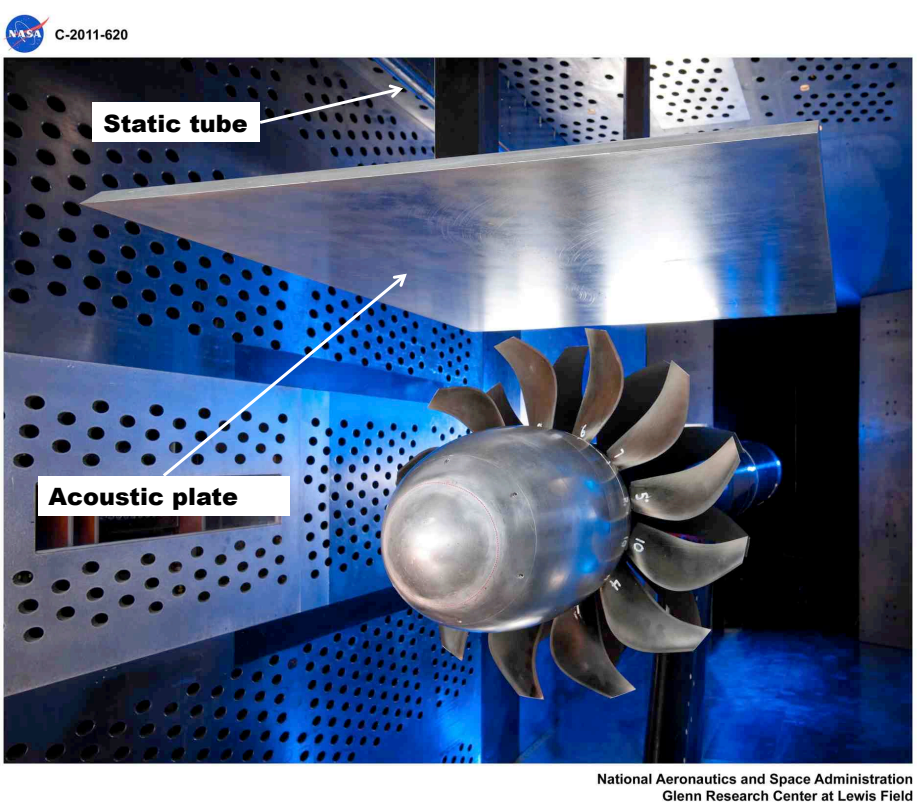




\section{Aerodynamic results}

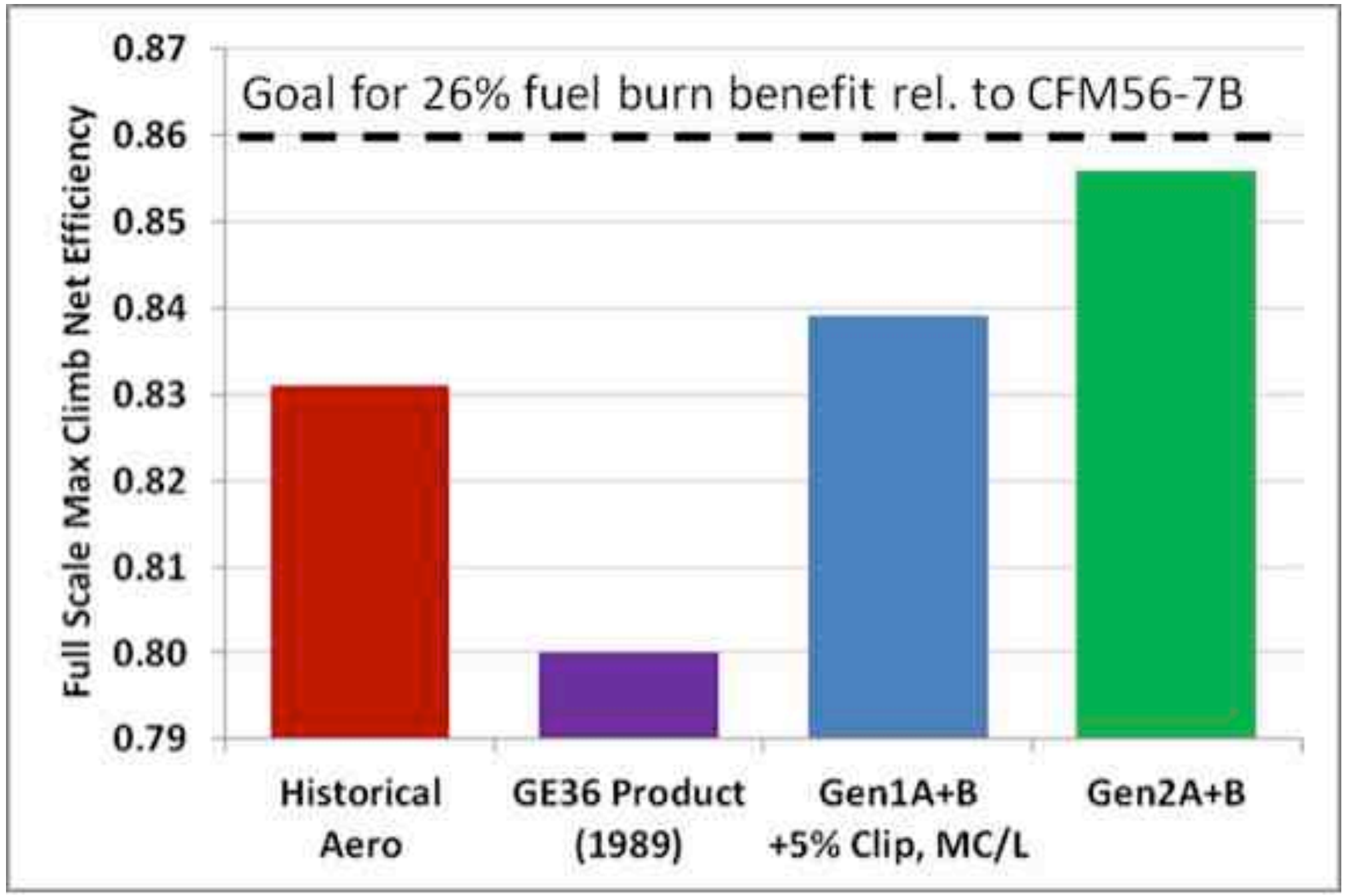

F31/A31 


\section{Acoustic results}

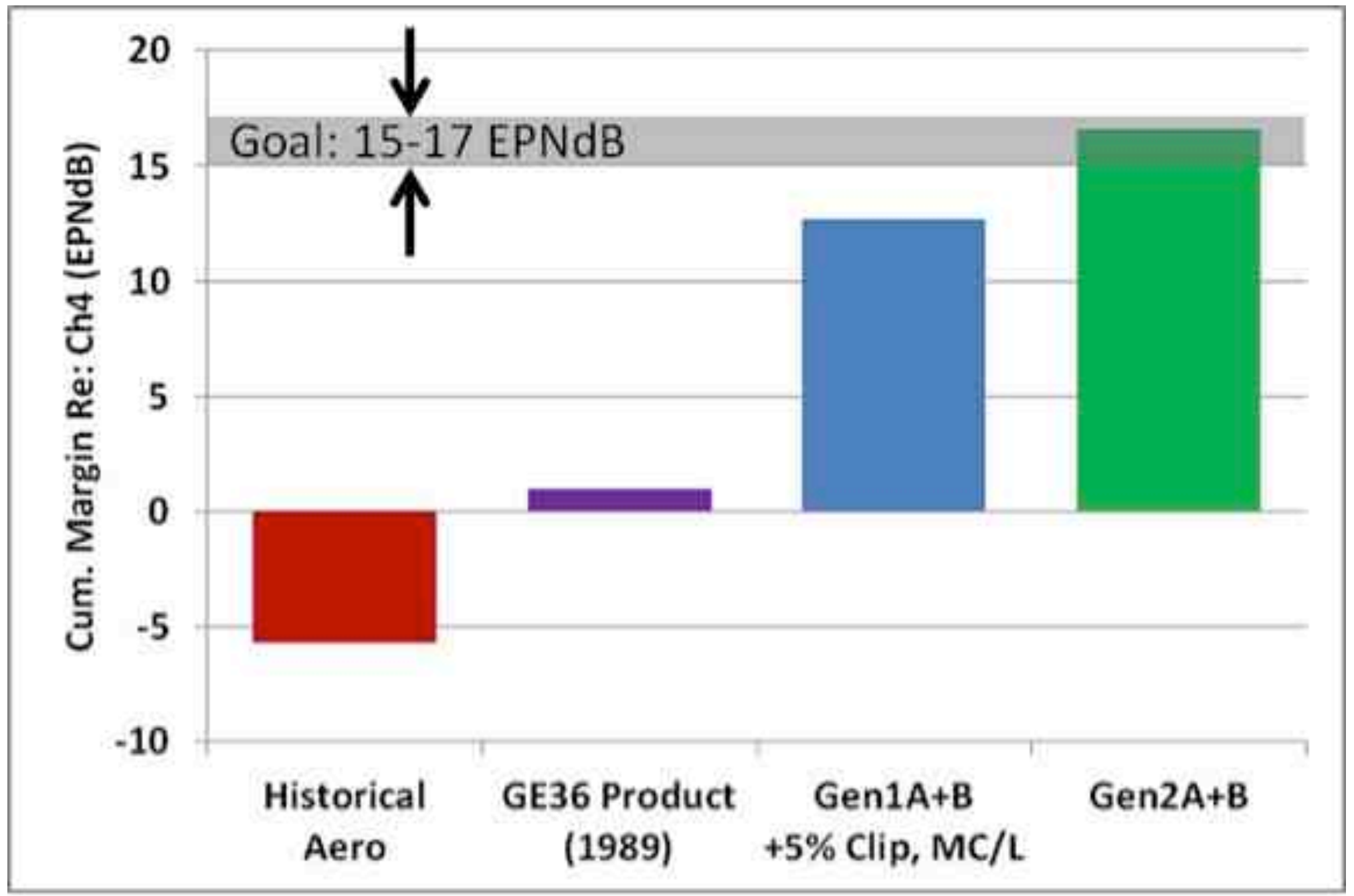

F31/A31 


\section{An assessment of the technology at TRL 4}

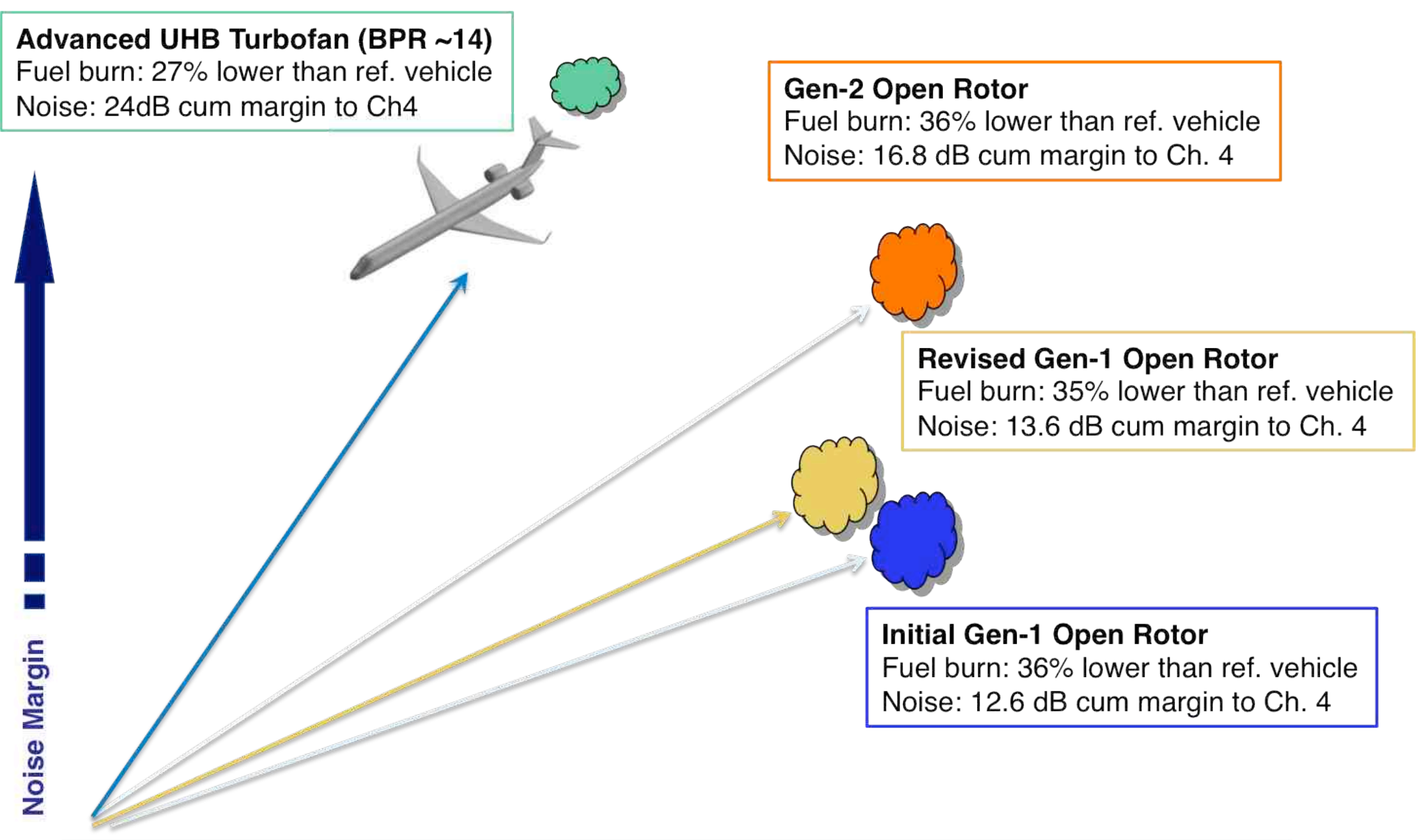

AIAA 2013-3628

\% Fuel Burn Benefit Relative to 1998

Technology Reference Vehicle 


\section{What remains to do?}

Propulsion Airframe Integration AoA into rotors Transonic performance

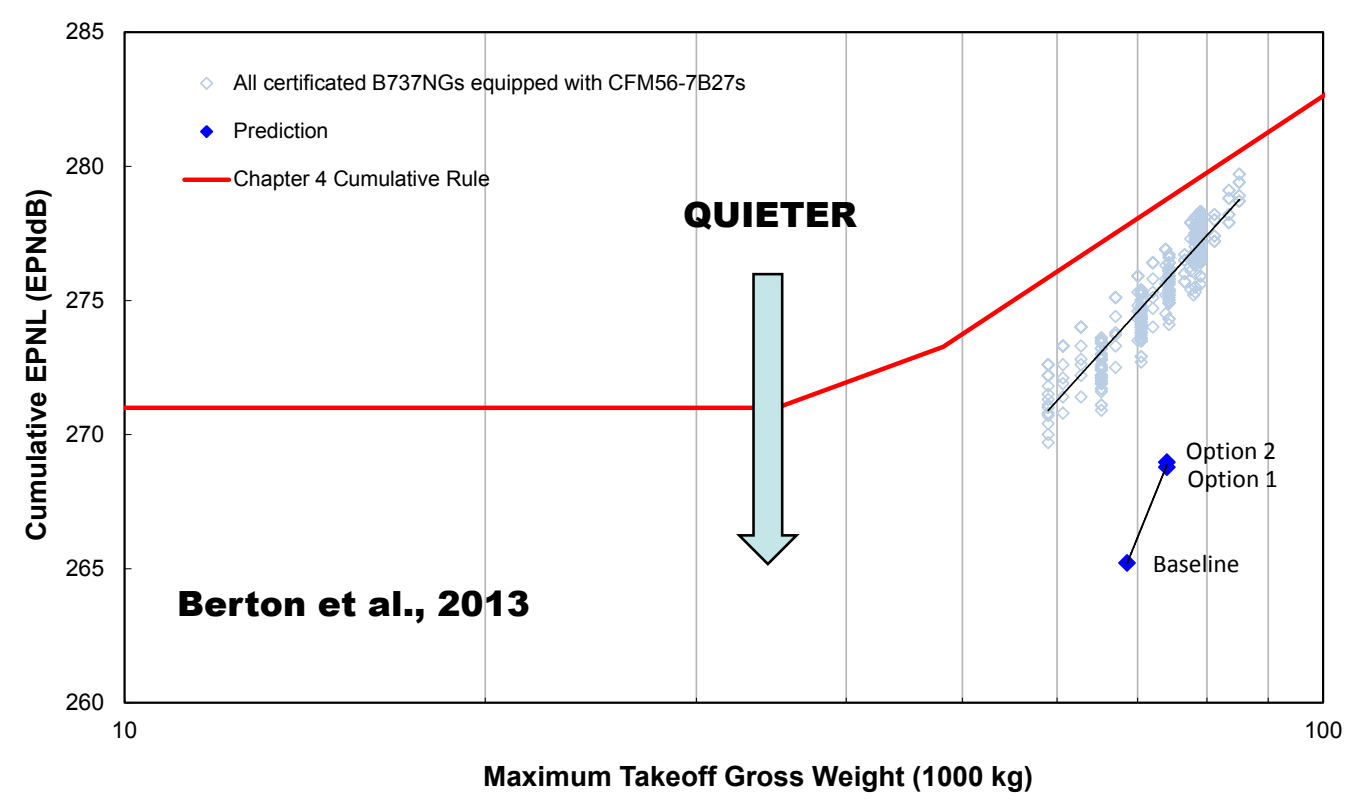

Technologies for additional noise margin

Technologies to address certification issues (EASA-ToR-MDM.092, 2011)

Nov 2014, Edmonton, CA

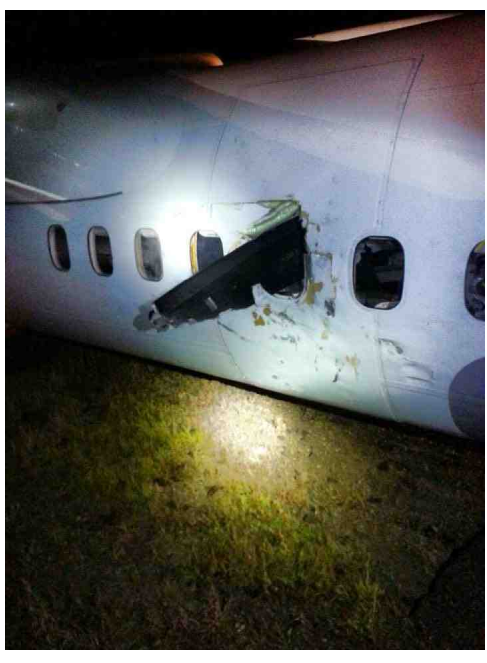

Need an airframe designed for use with an Open Rotor. 


\section{Summary}

- The current generation of Open Rotors is more efficient and significantly quieter than the legacy propfans.

- Challenges to implementation still exist: noise, propulsion-airframe integration, certification.

"The problem is developing a long-term energy plan that does not fluctuate with the changing price of oil and the changing demands of the market." -- from the Epilogue of SP-2009-574 
